\title{
KERAGAMAN GENETIK IKAN ENDEMIK BUTINI (Glossogobius matanensis) BERDASARKAN PENANDA RANDOM AMPLIFIED POLYMORPHISM DNA (RAPD) DI DANAU TOWUTI SULAWESI SELATAN
}

\author{
Jefry Jack Mamangkey*), Sulistiono ${ }^{* *}$, Djadja Subardja Sjafei ${ }^{* * *}$, Dedi Soedharma ${ }^{* *}$, \\ Sutrisno Sukimin ${ }^{* *)}$, dan Estu Nugroho ${ }^{* * *}$
}

\begin{abstract}
ABSTRAK
Evaluasi keragaman genetik ikan endemik butini yang diambil dari Danau Towuti Sulawesi Selatan dilakukan dengan menggunakan penanda RAPD. Sampel ikan dikoleksi dari Danau Towuti yang terbagi atas tiga zone dan masing-masing zone memiliki kedalaman $25 \mathrm{~m}, 75 \mathrm{~m}$, dan $150 \mathrm{~m}$. Tidak terdapat perbedaan genetik yang nyata antar ketiga zone dari masing-masing kedalaman. Heterozigositas berkisar antara $0,0491-0,1861$. Dendrogram berdasarkan 26 loci mengelompokkan secara garis besar kedalam dua kelompok yaitu kelompok ikan pada kedalaman 25-75 m dan kelompok ikan pada kedalaman $>150 \mathrm{~m}$.
\end{abstract}

\section{ABSTRACT: Genetic diversity of endemic fish butini (Glossogobius matanensis) base on markers Random Amplified Polymorphism DNA (RAPD) of Lake Towuti, South Sulawesi. By: Jefry Jack Mamangkey, Sulistiono, Djadja Subardja Sjafei, Dedi Soedharma, Sutrino Sukimin, and Estu Nugroho}

\begin{abstract}
Evaluation of genetic variability of endemic fish, butini which catched from Towuti Lake - South Sulawesi has been conducted based on the RAPD marker. Fish sample collected from Towuti Lake that divided into three zone and with depth of $25 \mathrm{~m}, 75 \mathrm{~m}$, and $150 \mathrm{~m}$. There is no significant differentiation genetically among fish from three zone and depth. Heterozygosity was range between 0.0491 to 0.1861 . Dendrogram based on the 26 loci divided the fish population generally into two group i.e. first group is consisted of fish collected from $25-75 \mathrm{~m}$ in depth and second one is constructed fish collected from $>150 \mathrm{~m}$ in depth.
\end{abstract}

KEYWORDS: diversity, genetic, butini, RAPD, Lake Towuti

\section{PENDAHULUAN}

Ikan butini (Glossogobius matanensis) merupakan salah satu spesies ikan yang terdapat di perairan umum Danau Towuti Sulawesi Selatan. Ikan ini termasuk ikan liar karena belum dibudidayakan. Ikan alami ini merupakan plasma nutfah yang sangat berharga bagi kehidupan manusia baik langsung maupun tidak langsung.
Menurut IUCN (1990), keberadaan ikan ini tergolong ikan yang rawan punah (vulnerable). Dari 87 jenis ikan Indonesia yang telah tercatat sebagai jenis ikan yang terancam punah, 66 spesies $(75,9 \%)$ di antaranya adalah ikan air tawar, diperkirakan dari 68,2\% ikan air tawar yang terancam punah ini adalah ikan endemik (Wargasasmita, 2005).

Berbagai aktivitas manusia menyebabkan lingkungan sumber daya ikan air tawar

\footnotetext{
Fakultas MIPA Universitas Negeri Manado, Sulawesi Utara

**) Fakultas Perikanan dan Ilmu Kelautan, Institut Pertanian Bogor, Bogor

***) Balai Riset Perikanan Budidaya Air Tawar, Bogor, Jawa Barat
} 
menghadapi ancaman menurunnya keanekaragaman ikan.Kepunahan ikan air tawar diperkirakan berkisar $78 \%$ yang disebabkan oleh perubahan habitat (Reid \& Miller, 1989). Selain itu, sebagian besar pemanfaatan perikanan sampai saat ini masih bersumber pada usaha penangkapan dari alam. Hal ini akan membawa pengaruh kurang menguntungkan bagi kontinuitas produksi.

Kegiatan penangkapan yang tidak terkontrol dapat mengarah pada hasil tangkap lebih (overfishing), sehingga berakibat menurunnya ketersediaan stok populasi ikan butini. Kelestarian sumber daya ini akan terancam apabila kegiatan penangkapan senantiasa dilakukan tanpa mengenal siklus hidup reproduksi untuk memberikan waktu dan peluang berkembang biak bagi jenis ikan butini di alam. Walaupun ikan termasuk sumber daya hayati yang mempunyai sifat dapat pulih kembali (renewable), namun apabila penangkapan dilakukan secara terus-menerus tanpa diimbangi dengan kegiatan yang mengarah pada upaya pelestariannya maka akan mengakibatkan penurunan populasi dan menuju kepada kepunahan.

Keragaman genetik yang dimiliki suatu spesies sangat mempengaruhi keberadaan dan kelestariannya di alam. Hilang atau berkurangnya keragaman genetik berdampak pada kemampuan regenerasi, pertumbuhan, dan perkembangan, serta daya tahan tubuh terhadap penyakit. Menurut Dunham (2002), variasi genetik penting untuk kelestarian jangka panjang suatu spesies atau populasi dan juga daya tahan spesies atau populasi untuk beradaptasi pada perubahan lingkungan. Keragaman genetik dalam populasi merupakan modal dasar aplikasi teknologi dalam pemanfaatan sumber daya ikan.

Penentuan variasi genetik pada ikan dapat dilakukan berdasarkan karakter morfologi dan genotipnya. Secara genotip, variasi genetik dapat dilakukan melalui pendekatan molekuler dengan berbagai macam metode, di antaranya dengan menggunakan Random Amplified Polimorphism DNA (RAPD). Pengembangan ikan-ikan endemik termasuk ikan butini merupakan salah satu cara yang selain dapat menyelamatkan ketersediaan stok alami juga merupakan mata pencaharian yang mampu mendatangkan uang dan devisa bagi negara (Sulistiono, 2004).

Oleh sebab itu, penting untuk menjaga populasi ikan agar tetap tinggi dan lestari, dengan mengetahui keragaman ikan endemik butini, mengidentifikasi pita DNA dari setiap sampel tiap kedalaman, menganalisis hubungan kekerabatan, dan menganalisis keanekaragaman karakter genetik plasma nutfah ikan butini di Danau Towuti. Hasil penelitian ini dapat dimanfaatkan untuk penentuan kebijakan pengelolaan karena pengetahuan dan informasi yang berkaitan

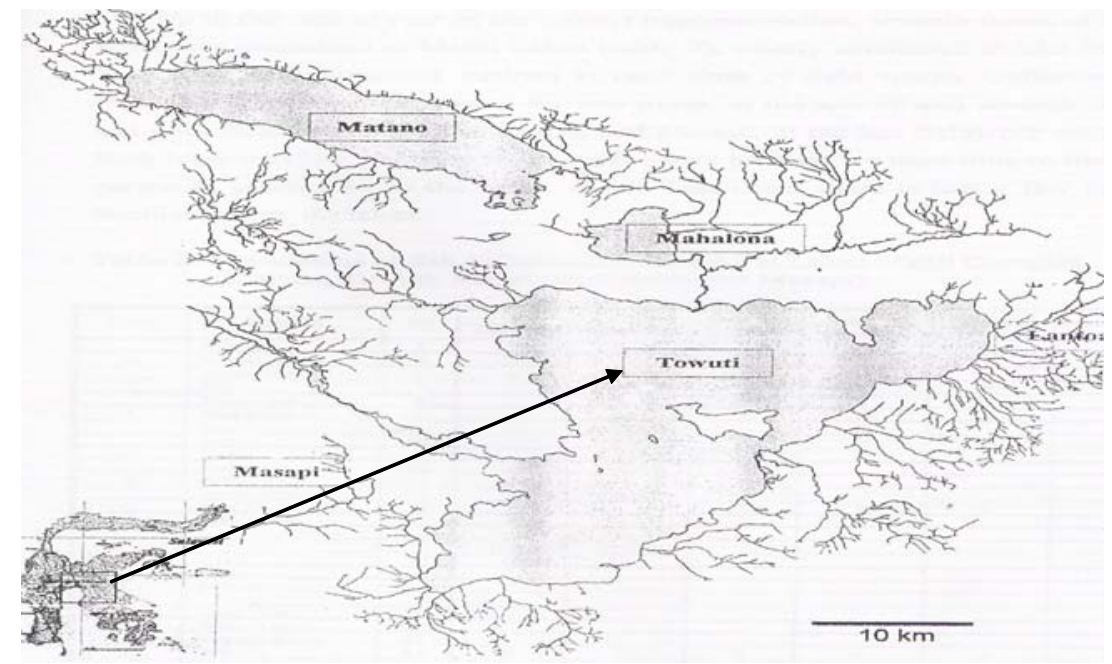

Sumber (Source): (Wirjoatmodjo et al., 2003)

Gambar 1. Peta Danau Towuti dan daerah kompleks Malili

Figure 1. Map of Towuti Lake and Malili complex area 
dengan ikan-ikan endemik yang ada di perairan ini masih sangat terbatas.

\section{BAHAN DAN METODE}

\section{Ikan sampel}

Ikan sampel yang digunakan dalam penelitian ini adalah ikan butini yang berasal dari Danau Towuti, Sulawesi Selatan. Pengambilan sampel dilakukan selama 12 bulan yaitu bulan April 2006-Mei 2007. Peta lokasi dapat dilihat pada Gambar 2.

Penelitian ini dilakukan dengan metode survey post facto berdasarkan bentuk, topografi, dan hidrologi dari Danau Towuti. Penetapan stasiun penelitian berdasarkan saluran masuk, saluran pembuangan, dekat pemukiman, buangan gergajian kayu. Zona I dekat pemukiman dan buangan gergajian kayu, terdiri atas kedalaman $25 \mathrm{~m}, 75 \mathrm{~m}$, dan $150 \mathrm{~m}$. Zona II dekat saluran masuk (masukan air dari sungai) terdiri atas kedalaman 25 m, 75 m, 150 m, dan $200 \mathrm{~m}$. Zona III dekat saluran pembuangan terdiri atas kedalaman $25 \mathrm{~m}, 75$ $\mathrm{m}$, dan $150 \mathrm{~m}$.

Ikan ditangkap menggunakan tiga rawai (long line), setiap rawai memiliki 200 matakail yang dapat dilihat pada Gambar 3. Sampel yang diperoleh pada setiap stasiun penelitian diambil dan diawetkan dalam larutan alkohol $70 \%$. Jumlah total sampel yang digunakan untuk pengamatan DNA adalah 30 ekor.

\section{Ekstraksi DNA}

DNA ikan diekstraksi dari potongan sirip dengan menggunakan metode PhenolChloroform, sebagai berikut: $5-10 \mathrm{mg}$ potongan sirip ikan dimasukkan kedalam tabung $1,5 \mathrm{~mL}$ yang telah berisi $500 \mu \mathrm{L}$ larutan lisis DNA + 120 larutan 0,5M EDTA pH 8,0. Kemudian ditambahkan $10 \mu \mathrm{g} / \mathrm{mL}$ protein kinase dan diinkubasikan pada suhu $55^{\circ} \mathrm{C}$ selama 3 jam. Sebanyak $3 \mu \mathrm{L}$ larutan Rnase ditambahkan kedalam campuran tersebut,

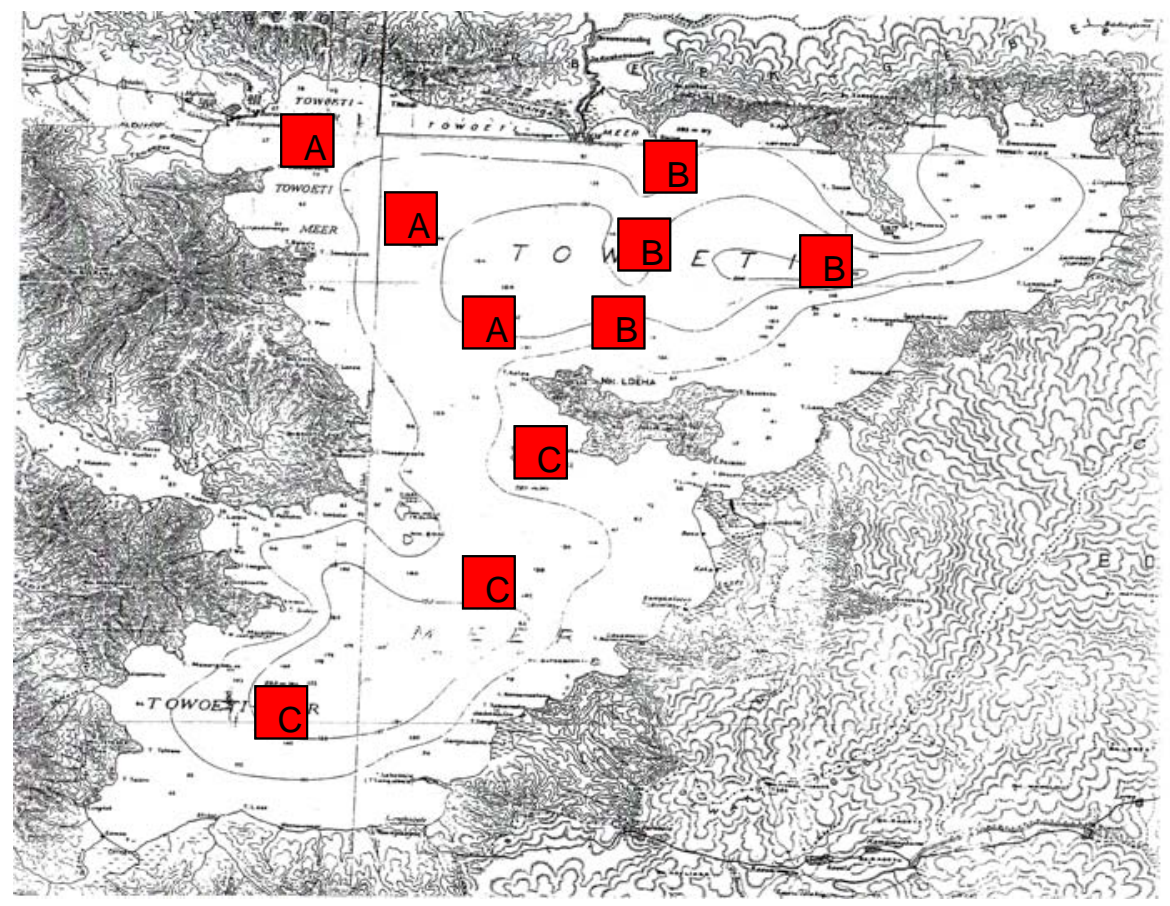

Keterangan (Note):

Zone I (A) = Saluran masuk (inlet), zone II (B) =Pemukiman dan pengergajian kayu (domestic area and sawmill), dan zone III (C) =Saluran pembuangan (outlet)

Gambar 2. Peta lokasi penelitian

Figure 2. Reseach location map 


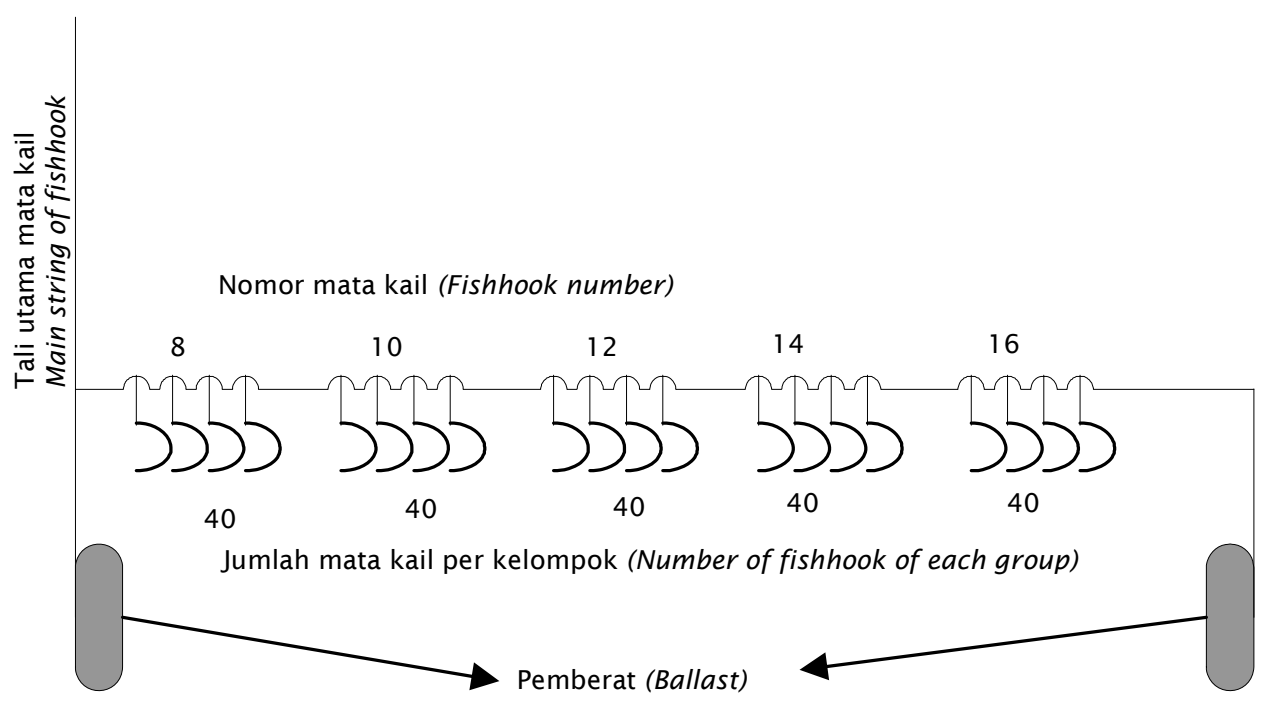

Gambar 3. Rancangan alat tangkap salue/rawai

Figure 3. Modification tools fishing long line

kemudian diinkubasikan pada suhu $37^{\circ} \mathrm{C}$ selama 30 menit. Setelah didinginkan pada suhu kamar, ditambahkan kedalamnya larutan Protein precipitation sebanyak $200 \mu \mathrm{L}$ dan disimpan dalam es selama 5 menit. Kemudian disentrifus pada kecepatan $10.000 \mathrm{rpm}$ selama 10 menit. Lapisan supernatannya diambil dan dimasukkan kedalam tabung baru, dan ditambahkan $600 \mu \mathrm{L}$ larutan propanol dan divortex sampai terlihat endapan putih. DNA diendapkan dengan cara mensentrifus campuran tersebut pada kecepatan 10.000 rpm selama 10 menit, kemudian larutan di atasnya dibuang dan DNA dikeringkan pada suhu ruangan. Kemudian dilarutkan kembali dalam 50-100 $\mu \mathrm{L}$ Tris-EDTA (TE) buffer dan disimpan dalam $4^{\circ} \mathrm{C}$ sebelum digunakan pada tahap selanjutnya.

\section{Random Amplified Polymorphism DNA (RAPD)}

Primer yang digunakan dalam RAPD adalah OPC 1 - OPC20 dan OPA 1 - OPA 20. Pengamplifikasian dilakukan menggunakan metode Polymerize Chain Reaction (PCR) dengan komposisi reaksi yang terdiri atas 10 $\mu \mathrm{g}, 10 \mathrm{pmol}$ primer dan pure taq DNA (Promega) dengan total volume keseluruhannya $25 \mu \mathrm{L}$. Siklus PCR yang digunakan dalam amplifikasi adalah satu siklus denaturasi pada suhu $95^{\circ} \mathrm{C}$ selama 4 menit. 35 siklus penggandaan yang terdiri atas $95^{\circ} \mathrm{C}$ selama 1 menit, $36^{\circ} \mathrm{C}$ selama 1 menit dan $72^{\circ} \mathrm{C}$ selama 2,5 menit.
Selanjutnya satu siklus terakhir pada suhu $72^{\circ} \mathrm{C}$ selama 10 menit. Hasil PCR kemudian dipisahkan secara elektroforesis dengan menggunakan gel agarose $2 \%$ - $3 \%$ dalam TrisBoric-EDTA (TBE) buffer dan diamati dengan illuminator (UV) serta dicetak gambarnya dengan polaroid.

\section{Analisis Data}

Untuk mengevaluasi variasi DNA antar kedalaman populasi ikan butini, digunakan Analysis Moleculer of Varians (AMOVA) dan Fst dalam program Tool for Population Genetik Analysis (TFPGA). Kekerabatan antar populasi dengan menggunakan Jarak Genetik (D) dianalisis berdasarkan Takezaki \& Nei (1996).

\section{HASIL DAN BAHASAN}

Dari dua jenis primer yang digunakan hanya primer OPA yang mempunyai hasil amplifikasi. Tiga primer tersebut adalah OPA 1, OPA 3, dan OPA 15. Primer OPA 3 mempunyai tipe amplifikasi yang paling variatif (polymorph) dengan jumlah loci 26 buah sedangkan dua primer lainnya adalah monomorph. Salah satu contoh hasil RAPD tertera pada Gambar 4.

Secara umum keragaman genetik ikan butini adalah relatif rendah berdasarkan nilai heterozigositas yang berkisar dari 0.0491 hingga 0,1861 dengan jumlah alel berkisar 30-39 alel pada 26 loci yang diuji (Tabel 1). 


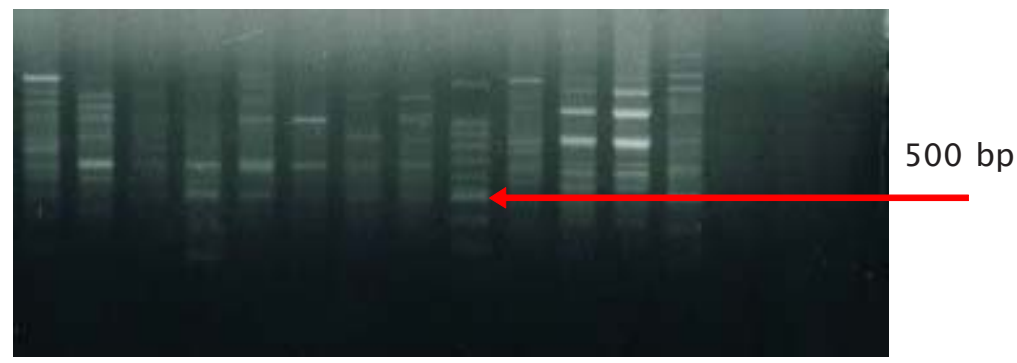

Gambar 4. Pola pita hasil amplifikasi dengan menggunakan primer OPA 3. M: marker ladder $100 \mathrm{bp}$. Tanda panah menunjukkan panjang $500 \mathrm{bp}$.

Figure 4. Band pattern of result of amplification with using primary OPA 3. M: marker ladder $100 \mathrm{bp}$. The Arrow show length $500 \mathrm{bp}$

Tabel 1. Keragaman genetik ikan butini yang dikoleksi pada berbagai kedalaman di tiga lokasi Danau Towuti Sulawesi Selatan.

Table 1. Genetik variation of fish butini collected at various deepness in three location of Lake Towuti, South Sulawesi

\begin{tabular}{|c|c|c|c|c|c|}
\hline & & \multicolumn{4}{|c|}{ Populasi (Population) } \\
\hline & & ZONE I & ZONE II & ZONE III & $\begin{array}{c}\text { Rat aan } \\
\text { (Average) }\end{array}$ \\
\hline \multirow{4}{*}{ 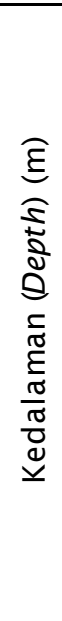 } & 25 & $\begin{array}{c}\mathrm{N}-\mathrm{S}=3 \\
\mathrm{~N}-\mathrm{A}=35 \\
\mathrm{He}=0.1255\end{array}$ & $\begin{array}{c}\mathrm{N}-\mathrm{S}=3 \\
\mathrm{~N}-\mathrm{A}=39 \\
\mathrm{He}=0.1861\end{array}$ & $\begin{array}{c}\mathrm{N}-\mathrm{S}=3 \\
\mathrm{~N}-\mathrm{A}=33 \\
\mathrm{He}=0.1024\end{array}$ & $\begin{array}{c}\mathrm{N}-\mathrm{S}=3 \\
\mathrm{~N}-\mathrm{A}=35 \\
\mathrm{He}=0.1378\end{array}$ \\
\hline & 75 & $\begin{array}{c}\mathrm{N}-\mathrm{S}=3 \\
\mathrm{~N}-\mathrm{A}=31 \\
\mathrm{He}=0.0576\end{array}$ & $\begin{array}{c}\mathrm{N}-\mathrm{S}=3 \\
\mathrm{~N}-\mathrm{A}=33 \\
\mathrm{He}=0.0879\end{array}$ & $\begin{array}{c}\mathrm{N}-\mathrm{S}=3 \\
\mathrm{~N}-\mathrm{A}=30 \\
\mathrm{He}=0.0491\end{array}$ & $\begin{array}{c}\mathrm{N}-\mathrm{S}=3 \\
\mathrm{~N}-\mathrm{A}=31 \\
\mathrm{He}=0.0649\end{array}$ \\
\hline & 150 & $\begin{array}{c}\mathrm{N}-\mathrm{S}=3 \\
\mathrm{~N}-\mathrm{A}=31 \\
\mathrm{He}=0.0794\end{array}$ & $\begin{array}{c}\mathrm{N}-\mathrm{S}=3 \\
\mathrm{~N}-\mathrm{A}=36 \\
\mathrm{He}=0.1587\end{array}$ & $\begin{array}{c}\mathrm{N}-\mathrm{S}=3 \\
\mathrm{~N}-\mathrm{A}=34 \\
\mathrm{He}=0.1139\end{array}$ & $\begin{array}{c}\mathrm{N}-\mathrm{S}=3 \\
\mathrm{~N}-\mathrm{A}=34 \\
\mathrm{He}=0.1173\end{array}$ \\
\hline & 200 & - & $\begin{array}{c}\mathrm{N}-\mathrm{S}=3 \\
\mathrm{~N}-\mathrm{A}=38 \\
\mathrm{He}=0.1818\end{array}$ & - & $\begin{array}{c}\mathrm{N}-\mathrm{S}=3 \\
\mathrm{~N}-\mathrm{A}=38 \\
\mathrm{He}=0.1818\end{array}$ \\
\hline \multicolumn{2}{|c|}{$\begin{array}{c}\text { Rataan } \\
\text { (Average) }\end{array}$} & $\begin{array}{c}\mathrm{N}-\mathrm{S}=3 \\
\mathrm{~N}-\mathrm{A}=32 \\
\mathrm{He}=0.0875\end{array}$ & $\begin{array}{c}\mathrm{N}-\mathrm{S}=3^{*} \\
\mathrm{~N}-\mathrm{A}=36^{*} \\
\mathrm{He}=0.1442 *\end{array}$ & $\begin{array}{c}\mathrm{N}-\mathrm{S}=3 \\
\mathrm{~N}-\mathrm{A}=32 \\
\mathrm{He}=0.0885\end{array}$ & \\
\hline
\end{tabular}

Keterangan: N-S= jumlah sampel; N-A= jumlah alel per 26 loci; He: heterozigositas; *) rata-rata dihitung per 3 kedalaman $(25 \mathrm{~m}, 75 \mathrm{~m}, 150 \mathrm{~m})$

Note: $N$-S = Sum sample; $N-A=S u m$ allele 26 loci; He: heterozygositas *) mean calculated by three deepness ( $25 \mathrm{~m}, 75 \mathrm{~m}, 150 \mathrm{~m}$ ) 

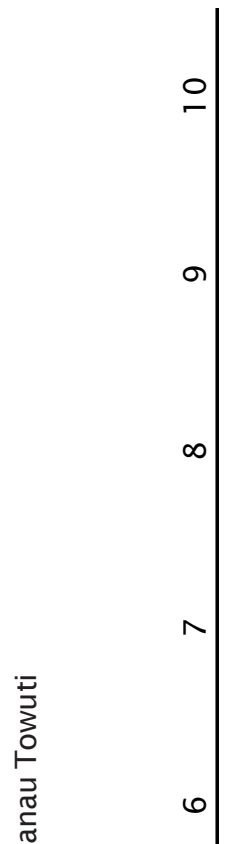

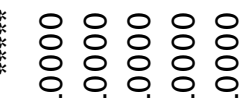

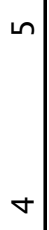

茫

$\frac{0}{\frac{2}{2}}$

g.

ปิ

은ㅇ

के

단

政

난

을

은

造

宁茫

$\frac{1}{0} \frac{1}{0}$

ㅇำ

$\frac{\pi}{2} \frac{2}{2}$

i

$\bar{d} \frac{1}{\frac{1}{2}}$

r

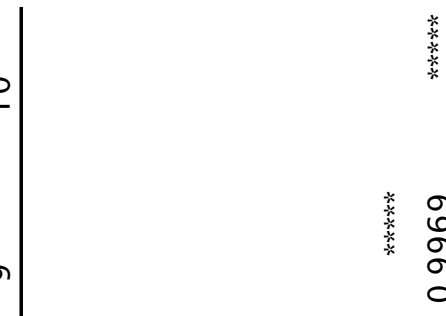

\begin{tabular}{l}
$\circ$ \\
$\circ$ \\
$\circ$ \\
$\circ$ \\
$\circ$ \\
\hdashline \\
- \\
-
\end{tabular}

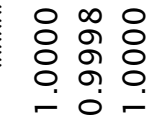

응ㅇㅇㅇㅇㅇㅇㅇㅇ 응ㅇㅇㅇㅇㅇ

- - - -

난 응ㅇㅇㅇㅇㅇㅇㅇㅇ

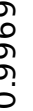

- - - - N

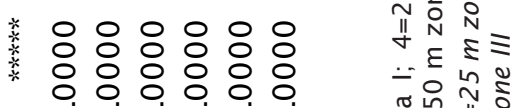
- - - - - D

이 0 o

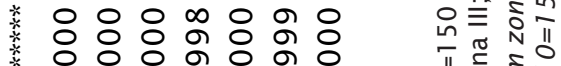

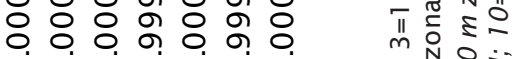

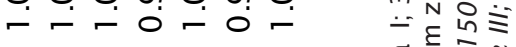
는 N ह ดे ई

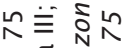

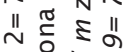
$\therefore$ 更 ㄷำ $\frac{1}{\sim}$

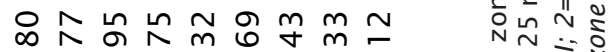

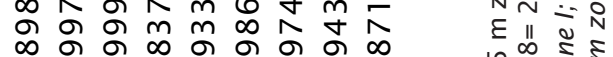

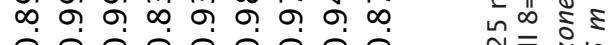
0 0000000 N $0^{\circ} N$

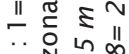
돈 $\stackrel{N}{\sim} \stackrel{\infty}{=}$ एँ 능 需只

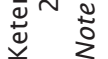


Keragaman genetik tersebut bervariasi sesuai dengan asal ikan. Ikan butini yang berasal dari zona II mempunyai nilai heterozigositas ratarata yang tertinggi yaitu 0,1442 (antara 0,0879-0,1861) dengan jumlah rata-rata alel 36 (antara 33-39 alel) diikuti ikan butini dari zona III dan I berturut-turut dengan nilai heterozigositas $0,0885(0,491-0,1139)$ dengan 32 alel (30-34 alel) dan 0,0875 $(0,0576-0,1255)$ dengan 32 alel $(31-35$ alel). $\mathrm{Hal}$ ini kemungkinan berkaitan dengan topografi, dimana zone II memiliki wilayah kedalaman $200 \mathrm{~m}$, sehingga ruaya ikan lebih luas dibanding zona lainnya.

Nilai keragaman ikan butini lebih rendah dibandingkan dengan jenis ikan laut seperti, kingfish, yellow tail, dan red sea bream (Nugroho, 2001). Rendahnya nilai keragaman genetik ini kemungkinan ada kaitannya dengan sifat migrasi pada ikan tersebut. Ikan-ikan air tawar, khususnya ikan butini yang juga disebut ikan malas diduga memiliki daerah migrasi yang tidak terlalu luas. Selain itu keberadaannya di Danau Towuti Sulawesi Selatan yang terisolir dari perairan umum lainnya yang memungkinkan terjadinya inbreeding.

Selanjutnya jika ditinjau dari tingkat kedalaman, ikan-ikan yang ditangkap pada kedalaman $25 \mathrm{~m}$ mempunyai keragaman genetik yang tertinggi dengan nilai heterozigositas rata-rata adalah 0,1378 (antara $0,1024-0,1861)$ dengan jumlah alel rata-rata 35 (antara 33-39 alel) dan diikuti oleh ikanikan yang tertangkap pada kedalaman $150 \mathrm{~m}$ dan $75 \mathrm{~m}$ dengan masing-masing nilai heterozigositas $0,1173(0,0794-0,1587)$ dengan jumlah alel rata-rata 34 (31-36 alel) dan $0,0649(0,0491-0,0879)$ dengan 31 alel (30-33 alel). Fenomena lebih tingginya keragaman genetik ikan butini pada kedalaman $25 \mathrm{~m}$ dan $150 \mathrm{~m}$ dibandingkan kedalaman "tengah" $75 \mathrm{~m}$ ini diduga karena ikan butini sebagai ikan dasar mempunyai keragaman yang lebih tinggi dan kemungkinan ikan butini sedang mencari makan di perairan "permukaan" yang yang relatif subur oleh adanya limbah dari pemukiman.

Analisis statistik dengan menggunakan AMOVA menunjukkan bahwa tidak terdapat perbedaan genetik secara nyata antara populasi ikan butini yang diuji $(P>0,05)$ berdasarkan polymorfisme RAPD. Uji berpasangan Fst menunjukkan bahwa semua perbandingan tidak berbeda nyata (Tabel 2 ). Keadaan ini mengindikasikan bahwa semua ikan butini yang berada di Danau Towuti berasal dari populasi yang sama. Tidak terdapat strukturisasi populasi berdasarkan lokasi dan kedalaman, salah satunya sebagai akibat adanya inbreeding dalam populasi tersebut.

Jarak genetik (D) yang dihitung menurut Takezaki dan Nei (1996) berdasarkan fragmen RAPD antara koleksi ikan butini tertera pada Tabel 3. Jarak genetik rata-rata antara populasi ikan butini adalah sekitar 0,272. Dendrogram pada Gambar 5 yang dibentuk berdasarkan jarak genetik tersebut menunjukkan bahwa

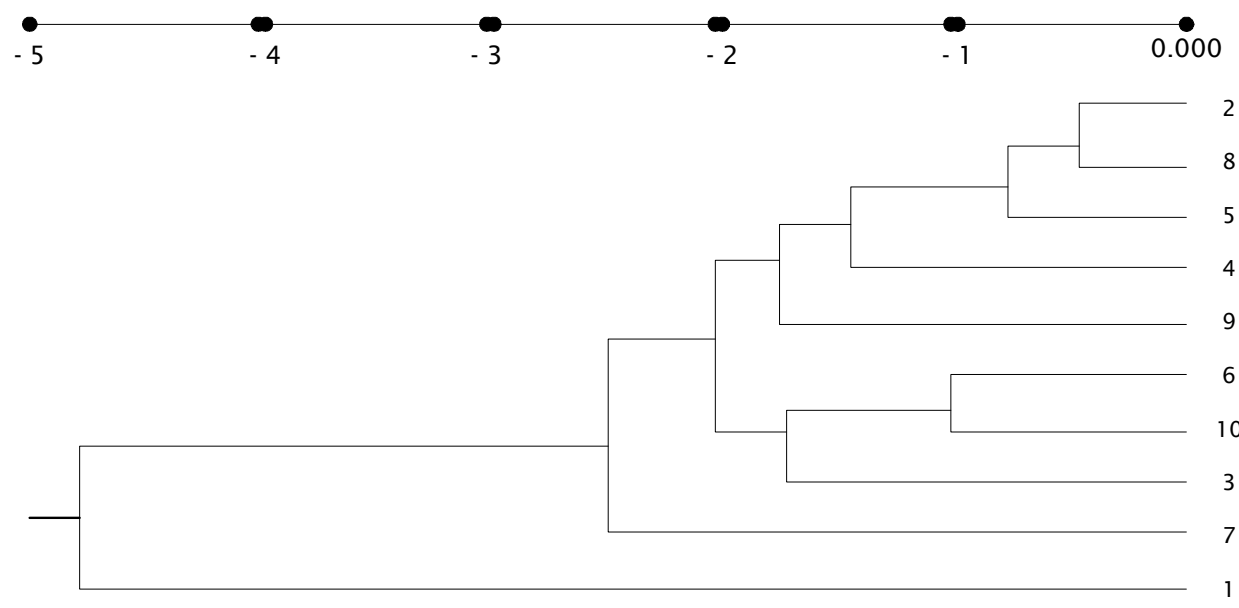

Gambar 5. Dendrogram populasi ikan endemik butini tiap kedalaman

Figure 5. Dendrogram population of endemic fish butini at various deepness 


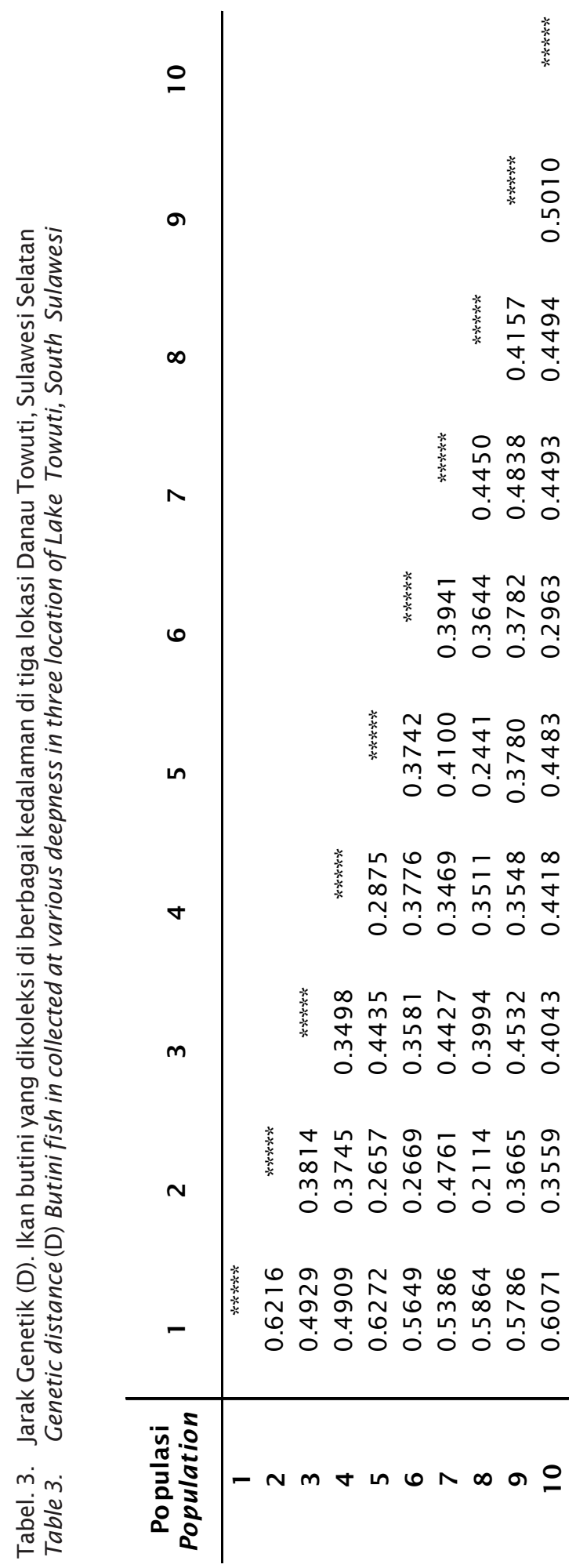


populasi butini di Danau Towuti dapat dikelompokkan menjadi dua grup besar yaitu, pertama terdiri atas ikan-ikan butini yang berasal dari kedalaman 25 dan $75 \mathrm{~m}$, sedangkan grup kedua terdiri atas ikan-ikan dari kedalaman $>150 \mathrm{~m}$. Nilai $\mathrm{D}$ pada ikan butini ini relatif lebih kecil dibandingkan jarak genetik antara ikan dari populasi yang terdiri atas subspesies yang sama, seperti pada ikan nila (Nugroho et al., 2002), king fish (Nugroho et al., 2001) dan greater amberjack (Nugroho et al., 2000). Keadaan ini mengindikasikan bahwa adanya kemungkinan ikan butini dari Danau Towuti masih berasal dari satu populasi. Hal ini perlu ditindak lanjuti lebih jauh lagi dengan dukungan informasi secara anatomi. Terpisahnya ikan butini dari zona A kedalaman $25 \mathrm{~m}$ dengan populasi ikan lainnya dimungkinkan adanya pengaruh dari lingkungan. Di mana zona A terletak pada daerah pemukiman yang memberikan tekanan pada populasi ikan di daerah tersebut.

\section{KESIMPULAN}

Tidak terdapat perbedaan genetik yang nyata antara ikan butini dari daerah 3 zona pada kedalaman $25 \mathrm{~m}, 75 \mathrm{~m}$, dan $150 \mathrm{~m}$ di Danau Towuti Sulawesi Selatan. Terdapat dua kelompok ikan butini berdasarkan kedalaman yaitu $25 \mathrm{~m}$ dan $75 \mathrm{~m}$ pada grup satu, dan kedalaman $>150 \mathrm{~m}$ pada grup dua.

\section{DAFTAR PUSTAKA}

Dunham, R.A. 2002. Aquaculture and Fisheries Biotechnology: Genetic Approach. CABI publishing, Cambridge, USA. 85-99 p.

IUCN. 1990. IUCN Red List of Threatened Animals. World Conservation Monitoring Centre Cambridge, U.K. 192 pp.

Nugroho, E., N. Taniguchi, K. Kato, and S. Miyashita. 2000. Genetic difference among seed populations of greater amberjack used in aquaculture farm of Japan. Suisanzoshoku. 48(4): 665-674.

Nugroho, E. 2001. Population Genetic Studies on the Aquaculture Fish in Genus Seriola for Their Risk Management. Disertasi. Tohoku University. $123 \mathrm{pp}$.

Nugroho, E., A.Widiyati, Imron, dan T. Kadarini. 2002. Keragaman Genetik Ikan Nila Gift Berdasarkan Polimorfisme Mitokondria DNA D-Loop. Jurnal Penelitian Perikanan Indonesia. 8(3): 1-6.

Reid, W.V. and K.R. Miller. 1989. Keeping Options Alive: The Scientific Basis for Conserving Biodiversity. World Resources Institute, Washington, D.C. 128 pp.

Sulistiono, 2004. Strategi Konservasi Melalui Teknik Penangkaran Jenis Ikan Langka Endemis Bonti-Bonti (Telmatherina spp.) Lembaga Penelitian dan Pemberdayaan Masyarakat, Institut Pertanian Bogor. 28 pp.

Takezaki, N. and M. Nei. 1996. Genetic Distance and Reconstruction of Phylogenetic Trees from Microsatellite DNA. Genetics. 144: 389-399.

Wargasasmita, S. 2005. Ancaman Invasi Ikan Asing Terhadap Keanekaragaman Ikan Asli. Jurnal Iktiologi Indonesia. 5 (1): 5-10. 